\title{
Concerned doctor and an apprehensive patient: case of calcified bilateral vas deferens
}

\author{
Sagib Mehdi, Samarth Agarwal,,$^{\ominus}$ Manoj Kumar, Satyanarayan Sankhwar
}

Urology, King George's Medical University, Lucknow, Uttar Pradesh, India

\section{Correspondence to} Professor Satyanarayan Sankhwar, sankhwarsn_sn@yahoo.com

Accepted 3 June 2019
A 50-year-old man had presented to a medical facility with history of fall from height. As a part of the evaluation process to rule out any bony injuries, the patient was advised an X-ray of the pelvis. Fortunately, for the patient there were no injuries detected on the X-ray but two radio-opaque tubular shadows were visible in the pelvis (figure 1). This finding intrigued the treating physician as much as it added to the apprehension of the patient. The patient was referred to our facility to rule out any sinister pathology. On carefully studying the X-ray of the patient, we were able to elucidate that the course of the shadows mimicked the typical intrapelvic course of the vas deferens moving towards inguinal canal. The shadows were almost bilaterally symmetrical, regular and the intraluminal patency on both sides seemed to be maintained. Patient had a known history of diabetes mellitus for last 10 years. His serum parameters revealed elevated blood sugars (glycosylated haemoglobulin $8.4 \%$ ) while other parameters of his metabolic profile were umremarkable. The patient had completed his family, and was explained about the nature of the disease that needed no further investigations or treatment. He was advised to follow-up with an endocrinologist for treatment of his diabetes mellitus.

Calcification of vas deferens is a rare condition which was first described by Marks and Ham. ${ }^{1}$

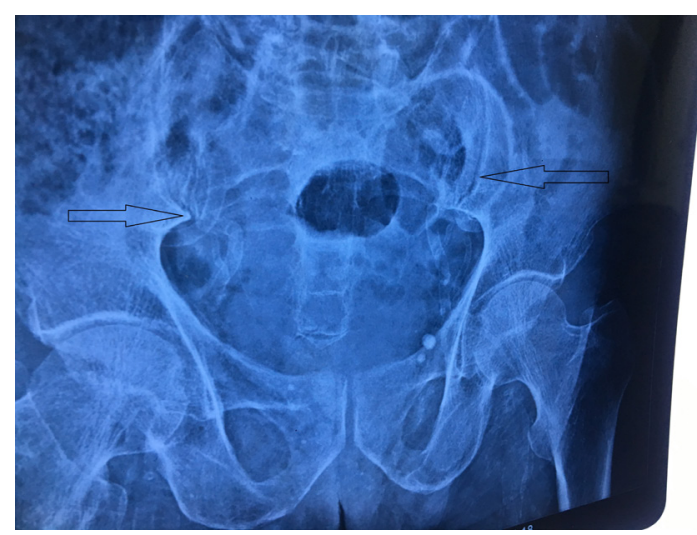

Figure 1 X-ray pelvis of the patient showing the presence of two radio-opaque, almost bilaterally symmetrical tube like structures mimicking the intrapelvic course of vas deferens.

\section{Learning points}

- Emphasis should be laid on this incidental finding on radiograph as missing it may lead to unnecessary apprehension of the patient and prompt unwarranted investigations.

- Patient with calcification of the vas should be investigated to rule out any underlying metabolic or chronic inflammatory condition.

- The patients should be counselled regarding the benign nature of the disease to allay any unnecessary fears and apprehensions.

Although diabetes is a common association with calcification of vas, various chronic inflammatory conditions like tuberculosis have also been incriminated. The calcification of vas is usually bilateral, symmetrical and regular in diabetics which differentiates it from that of chronic inflammatory conditions. Also, the intraluminal patency of vas deferens seems to be maintained in diabetics as the calcification occurs in muscular layer of the vas. The calcification should also be differentiated from the linear calcifications of blood vessels in the pelvis. The patients need to be evaluated for the underlying condition and the benign nature of the condition should be explained to the patient. ${ }^{23}$

Contributors SM conceived the case report. SM and SA were major contributors towards writing the manuscript. SM, MK and SNS treated the patient and also interpreted the patient data. SA and MK were involved in the review. All authors read and approved the final manuscript.

Funding The authors have not declared a specific grant for this research from any funding agency in the public, commercial or not-for-profit sectors.

Competing interests None declared.

Patient consent for publication Obtained.

Provenance and peer review Not commissioned; externally peer reviewed.

\section{REFERENCES}

1 Marks JH, Ham DP. Calcification of vas Deferens. AJR Am J Roentgenol 1942;47:859.

2 Newmark H, Bigelow L. Vas deferens calcification seen on computerized tomography. Comput Radiol 1985;9:377-8.

3 Pandey S, Kundu A, Mehdi S, et al. Bilateral serpentine radioopaque shadows near the urinary bladder: nothing but calcified vas deferens!. BMJ Case Rep 2018;2018:bcr-2018-225319. 
Copyright 2019 BMJ Publishing Group. All rights reserved. For permission to reuse any of this content visit https://www.bmj.com/company/products-services/rights-and-licensing/permissions/

BMJ Case Report Fellows may re-use this article for personal use and teaching without any further permission.

Become a Fellow of BMJ Case Reports today and you can:

- Submit as many cases as you like

Enjoy fast sympathetic peer review and rapid publication of accepted articles

Access all the published articles

Re-use any of the published material for personal use and teaching without further permission

Customer Service

If you have any further queries about your subscription, please contact our customer services team on +44 (0) 2071111105 or via email at support@bmj.com.

Visit casereports.bmj.com for more articles like this and to become a Fellow 